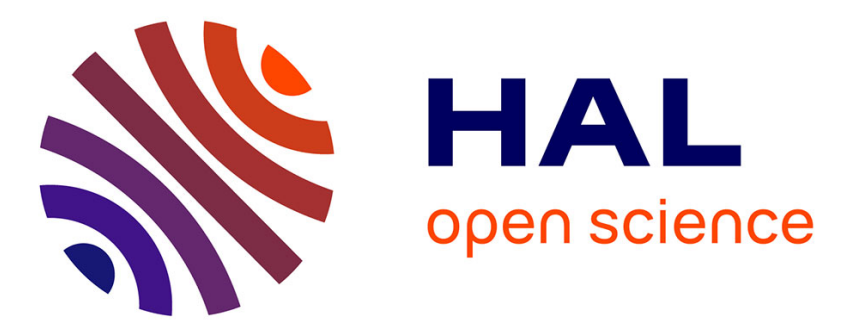

\title{
Influence of p-isopropenylcalixarenestyrene copolymer buffer layer over Alq based OLEDs
}

P. K. Petrova, R. L. Tomova, R. T. Stoycheva-Topalova, St. M. Miloshev

\section{To cite this version:}

P. K. Petrova, R. L. Tomova, R. T. Stoycheva-Topalova, St. M. Miloshev. Influence of pisopropenylcalixarenestyrene copolymer buffer layer over Alq based OLEDs. European Physical Journal: Applied Physics, 2010, 51 (3), pp.33210. 10.1051/epjap/2010111 . hal-00618495

\section{HAL Id: hal-00618495 \\ https://hal.science/hal-00618495}

Submitted on 2 Sep 2011

HAL is a multi-disciplinary open access archive for the deposit and dissemination of scientific research documents, whether they are published or not. The documents may come from teaching and research institutions in France or abroad, or from public or private research centers.
L'archive ouverte pluridisciplinaire HAL, est destinée au dépôt et à la diffusion de documents scientifiques de niveau recherche, publiés ou non, émanant des établissements d'enseignement et de recherche français ou étrangers, des laboratoires publics ou privés. 


\title{
Influence of $p$-isopropenylcalixarenestyrene copolymer buffer layer over $\mathrm{Alq}_{3}$ based OLEDs
}

\author{
P. K. Petrova ${ }^{1, *}$, R. L. Tomova ${ }^{1}$, R. T. Stoycheva-Topalova ${ }^{1}$, St. M. Miloshev ${ }^{2}$ \\ ${ }^{1}$ Central Laboratory of Photoprocesses “Acad. J. Malinowski”, Bulgarian Academy of Sciences, “Acad. G. \\ Bonchev"str., bl. 109, 1113 Sofia, Bulgaria \\ *Corresponding author. Tel. +359 (2) 979 3543; Fax. +359 (2) 8720073 \\ E-mail address: Petia@clf.bas.bg; Petiakl@mail.bg \\ ${ }^{2}$ Department of Polymer Engineering, Faculty of Chemistry Technology, University of Chemical Technology \\ and Metallurgy, Kliment Ohridsky Boulevard 8, 1756 Sofia, Bulgaria \\ PACS: 73.61.Ph, 78.60.Fi, 78.66.Qn
}

\begin{abstract}
The characteristics of organic light-emitting devices based on aluminum tris-(8-hydroxyquinoline) $\left(\mathrm{Alq}_{3}\right), N, N^{\prime}$-bis(3-methylphenyl)- $N, N^{\prime}$-diphenylbenzidine (TPD) with novel $p$-Isopropenylcalix[8]arenestyrene copolymer buffer layer and $\mathrm{Al}$ cathode were investigated. The devices with $\mathrm{TPD} / \mathrm{Alq}_{3} / \mathrm{Al}$ were also fabricated in the same way for comparison. The $p$-Isopropenylcalix[8]arenestyrene copolymer used as buffer layer greatly improved the performance of the device and increased the device efficiency and stability.
\end{abstract}

\section{Introduction}

Since efficient green electroluminescence from an organic light emitting device (OLED) was first reported [1], there has been considerable interest in utilizing OLEDs for full color flat panel display applications. Early investigations indicated that OLEDs have a limited lifetime, characterized by a decrease in EL efficiency and an increase in drive voltage. To enhance the efficiency, to prolong the durability and to lower the driving voltage of OLEDs continue to be the key challenges to meet the requirements of practical application in flat panel display technology. The performance of OLED is affected not only by the properties of its constituent organic layers but also by the electrodes and their interfaces with charge-transporting layers. One of practical approach to improve interfacial properties especially electrode/organic contact behaviors is to insert a thin buffer layer between the electrodes and the organic transporting layers. The quality of a buffer layer in OLED is a crucial factor for driving voltage, power efficiency and stability of a device.

A variety of inorganic insulators like transparent metal oxides as $\mathrm{SiO}_{2}, \mathrm{Al}_{2} \mathrm{O}_{3}, \mathrm{CuO}_{\mathrm{x}}$ $\mathrm{Pr}_{2} \mathrm{O}_{3}, \mathrm{Y}_{2} \mathrm{O}_{3}, \mathrm{~Tb}_{4} \mathrm{O}_{7}, \mathrm{ZnO}$ [2], $\mathrm{NiO}$ [3], $\mathrm{WO}_{3}$ [4], $\mathrm{MoO}_{\mathrm{x}}$ [4], $\mathrm{V}_{2} \mathrm{O}_{5}$ [5], silicon nitride $\mathrm{Si}_{3} \mathrm{~N}_{4}$ [2], carbon nitride a-C:N [6], organic compounds such as, copper phthalocyanine [7], $\operatorname{poly}(3,4-$ ethylenedioxythiophene) [8], Langmuir-Blodjett films of poly(methylmethacrylate) [9], polytetrafluoroethylene [10], fluoropolymers [11], fluorene-based poly(iminoarylene)s [12], $\alpha$ Septithiophene [13], etc. have been tested as the buffer layers.

In this paper, we offer for the first time $p$ Isopropenylcalix[8]arenestyrene copolymer (iPrCS) as a novel buffer layer for the fabrication of OLED with improved efficiency and life time. Until now the calix[4]arene compounds were used only for design of electroluminescent complexes - for ex. a calix[4]arene $[\mathrm{Al} \mathrm{I}]^{3+}$ complex [14], lanthanide complexes with calix[4]arene derivatives [15].

\section{Experimental}

Two types of devices were investigated: $\mathrm{ITO} / \mathrm{iPrCS} / \mathrm{TPD} / \mathrm{Alq}_{3} / \mathrm{Al}$, and ITO/TPD/Alq $/ \mathrm{Al}$ as a reference structure.

Materials: The $p$-Isopropenylcalix[8]arenestyrene copolymer employed for this study (Fig.1) was obtained according to described procedure [16]. $\mathrm{Alq}_{3}, \mathrm{TPD}$, and polyethylene terephtalate (PET) substrates coated with ITO $(40 \Omega / s q)$ were purchased from Aldrich and used as received.

Device fabrication: Devices with area $1 \mathrm{~cm}^{2}$ were prepared on commercial ITO ( $40 \Omega / \mathrm{sq})$ as the anode material. A $5 \mathrm{~mm}$ wide ITO strip line was formed on PET substrates by selective etching in hydrochloric acid $(\mathrm{HCl})$ and nitric acid $\left(\mathrm{HNO}_{3}\right)$ with a volume ratio $\mathrm{HCl}: \mathrm{HNO}_{3}: \mathrm{H}_{2} \mathrm{O}=1: 1: 2$ for 1 min at room temperature. Then the patterned ITO substrate was cleaned in acetone, isopropanole and rinsed in deionized water.

The buffer layer $(\delta=10-16 \mathrm{~nm})$ of iPrCS was deposited onto PET/ITO substrates by spin-coating from $0.1-0.3 \%$ solution in THF (filtered through a $0.8 \mu$ PA filter) at $2000 \mathrm{rpm}$.

The hole transporting TPD layer (HTL) $(\delta=30$ $\mathrm{nm})$, the emissive layer (EL) of $\mathrm{Alq}_{3}(\delta=50,75$ $\mathrm{nm})$ and the Al cathode $(\delta=120 \mathrm{~nm})$ were obtained by thermal evaporation in a vacuum better than $10^{-4}$ $\mathrm{Pa}$ at rates of $2-5 \mathrm{~A} / \mathrm{s}$.

Measurements: TGA measurement was carried out from Perkin Elmer TGA at a linear heating rate of $10^{\circ} \mathrm{C} \min ^{-1}$ under highly pure nitrogen gas. Temperature was ranged from ambient to $750^{\circ} \mathrm{C}$. The weight of sample was $18 \mathrm{mg}$. 
The morphologies of the deposited buffer layer, HTL and EL were studied with a scanning electron microscopy (SEM) (Philips 515).

The current-voltage $(\mathrm{I} / \mathrm{V})$ and luminescencevoltage $(\mathrm{L} / \mathrm{V})$ curves were automatically measured with an "Organic LED Monitor 1000" system produced by "Advanced Technologies Ltd." in continuous DC mode, where the light output was detected using a calibrated silicon photodiode Hamamatsu S 2281.

The luminous efficiency $\left(\eta_{L}\right)$ in candelas per amp [cd/A], calculated by Eq. 1, was used for quantifying the properties of the OLEDs [17].

$$
\eta_{L}=L / I
$$

The devices were characterized in room ambient and temperature without encapsulation.

\section{Results and discussion}

\subsection{Effect of morphology}

SEM micrographs of the studied layers were presented on figure 2. The surface of iPrCS thin film deposited on ITO (Fig.2a) is amorphous and very smooth. TPD thin film sample, deposited upon iPrCS layer (Fig.2c) has a more ordered surface texture. The vacuum deposited TPD layer on a bare ITO (Fig.2d) shows a granular structure with bubbles, which is a prerequisite for recrystallization and oxidation. A dense and smooth surface image of $\mathrm{Alq}_{3}$ thin film was found, with no defects observed in OLED with buffer layer (Fig.2e). Not so smooth is the surface of $\mathrm{Alq}_{3}$ thin film in the structure without buffer layer (Fig.2f).

The used by us iPrCS has high thermal stability and good film formability. The TGA obtained shows that the copolymer undergoes a small $9.906 \%$ weight loss transition at $193^{\circ} \mathrm{C}$, and thermal degradation beginning at $397.48{ }^{\circ} \mathrm{C}$ with mass loss of $52.20 \%$.

Besides ITO is known to form an excellent electrode, its morphology can gradually affect the organic layers evaporated on ITO substrate, where the small spikes in the ITO surface can lead to local crystallization of HTL and EL causing a bright white-spot that may increase the leakage and instability of the device. The amorphous and very smooth surface of spin-coated thin film of iPrCS creates more suitable conditions for vacuum deposition of TPD thin films compared to the bare ITO and improves substantially the thermal stability of TPD during the operation of the devices. The results obtained show that the buffer layer of $i \operatorname{PrCS}$ copolymer modifies successfully the film morphology thus preventing the recrystallization of hole transporting layer (TPD) and emissive layer $\left(\mathrm{Alq}_{3}\right)$.

\subsection{OLEDs performance}

The characteristics of OLEDs were studied in dependence on the thickness of iPrCS buffer layers.
Figure 3 presents typical nonlinear current/voltage (I-V) (Fig.3a), luminance/voltage (L-V) (Fig.3b) and efficiency characteristics (Fig.3c) of ITO/iPrCS $(10-16 \mathrm{~nm}) / \mathrm{TPD}(30 \mathrm{~nm}) / \mathrm{Alq}_{3}(50 \mathrm{~nm}) / \mathrm{Al}$, and ITO/TPD $(30 \mathrm{~nm}) / \mathrm{Alq}_{3}(50 \mathrm{~nm}) / \mathrm{Al}$ as a reference structure. It was shown that the luminance and efficiency of the devices depends substantially on the thickness of the buffer layers. The most suitable thickness of the buffer layer is $13 \mathrm{~nm}$. The efficiency of the device with $13 \mathrm{~nm}$ iPrCS is nearly $80 \%$ higher than that of the reference structure.

Later, we studied the effect of the thickness of $\mathrm{Alq}_{3}$ on the performance of the devices with iPrCS films. The current/voltage (I-V), luminance/voltage (L-V) and efficiency characteristics of the ITO/iPrCS $(13 \mathrm{~nm}) / \mathrm{TPD}(30 \mathrm{~nm}) / \mathrm{Alq}_{3} \quad(50,75$ $\mathrm{nm}) / \mathrm{Al}$, and $\mathrm{ITO} / \mathrm{TPD} / \mathrm{Alq}_{3}(50,75 \mathrm{~nm}) / \mathrm{Al}$ as the reference structures were presented on figure 4 . It was established that the luminance (fig.4b) and efficiency (fig.4c) of the devices with iPrCS are much higher compared to the similar reference structures. The devices with $13 \mathrm{~nm}$ buffer layer and emissive layer of $75 \mathrm{~nm} \quad \mathrm{Alq}_{3}$ have best characteristics.

The results obtained in this paper showed that the buffer layer of iPrCS greatly improves the performance of OLEDs - decreases the turn-on and the driving voltage, increases the brightness and the efficiency and prolong the life time. Besides that the turn-on and the driving voltage especially for the reference structure are still relatively high, the current efficiencies of the studied devices are close to the results of the other authors. The efficiency of our reference structure with $75 \mathrm{~nm} \mathrm{EL}$ of $\mathrm{Alq}_{3}$ at luminance $100 \mathrm{~cd} / \mathrm{m}^{2}$ is $1.89 \mathrm{~cd} / \mathrm{A}$ at current density of $5.3 \mathrm{~mA} / \mathrm{cm}^{2}$ while the efficiency of the OLED with buffer layer of iPrCS at luminance $100 \mathrm{~cd} / \mathrm{m}^{2}$ increases more than $1.5 \mathrm{x}-$ up to $3.11 \mathrm{~cd} / \mathrm{A}$ at current density of $3.2 \mathrm{~mA} / \mathrm{cm}^{2}$. The maximum efficiency of the devices with $\mathrm{iPrCS}$ is $3.54 \mathrm{~cd} / \mathrm{A}$, similar to those of Okamoto $-3.4 \mathrm{~cd} / \mathrm{A}$ at current density of $20 \mathrm{~mA} / \mathrm{cm}^{2}$ for structure ITO/CF $/ \mathrm{NPB}$ $(60 \mathrm{~nm}) / \mathrm{Alq}_{3}(60 \mathrm{~nm}) / \mathrm{LiF} / \mathrm{Al}$ [18]. An efficiency of $4.46 \mathrm{~cd} / \mathrm{A}$ at a current density of $200 \mathrm{~mA} / \mathrm{cm}^{2}$ was achieved with ITO/PFA $(10 \mathrm{~nm}) / \mathrm{Alq}_{3}(60 \mathrm{~nm}) /$ $\mathrm{Mg}: \mathrm{Ag} / \mathrm{Ag}$ device by H.Wang et al. [11]. The luminescence of OLED with buffer layer increases $3 \mathrm{x}$, the operational stability $-4 \mathrm{x}$, while the driving voltage decreases about $30 \%$ compared to the reference structure. It was established that the iPrCS buffer layer substantially modify the morphology of the next hole transporting and emissive layer thus creating the conditions for obtaining of very reproducible and bright OLED with very good performance and better life time. It could be supposed that besides the $\operatorname{PrCS}$ is an insulator, it seems to enhance the hole injection thus improving a hole-electron balance in OLED. The calixarenes are a class of bowl-shaped cyclooligomeres obtained via phenol-formaldehyde 
condensation with a defined upper and lower rim, and a cavity. This speciality enable them to act as host molecules due to their cavities, and allow utilized them as chemical sensors, extractants for radioactive waste processing, materials for nonlinear optics, bio-active compounds. The molecular structure of used by us for the first time novel buffer layer of calixarenes makes the tunneling injection in OLED very probable.

\section{Conclusion}

For the first time the $p$-Isopropenylcalix [8]arenestyrene copolymer is proposed as a buffer layer for the obtaining of OLED. It was established that the buffer layer lowers the turn-on and the driving voltage, increases the luminance and efficiency and improves the life time of OLED compared to the devices without buffer layer.

The characteristics of OLED with different thickness of buffer layer and emissive layer have been investigated. It was found that the best characteristics have OLEDs with $13 \mathrm{~nm} p$ Isopropenylcalix[8]arenestyrene copolymer buffer layer and emissive layer of $75 \mathrm{~nm} \mathrm{Alq}_{3}$. Even though more detailed investigations on the mechanisms due to the incorporation of $p$ Isopropenylcalix[8]arenestyrene copolymer buffer layer still remain to be carried out the results obtained are very promising for further improvement of OLED performance.

\section{References}

[1] C. W. Tang, S. A. VanSlyke, Appl. Phys. Lett. 51, 913 (1987)

[2] X.Xu, G. Yu, Y. Liu, D. Zhu, Displays, 27, 24 (2006)

[3] H.C.Im, D.C.Choo, T.W.Kim, J.H.Kim, J.H.Seo, Y.K.Kim, Thin Solid Films 515, 5099 (2007)

[4] X.Y.Jiang, Z.L.Zhang, J.Cao, M.A.Khan, K.Haq, W.Q.Zhu, J.Phys.D: Applied Physics 40, 5553 (2007)

[5] F.Guo, D.G.Ma, Appl. Phys. Lett. 87, 173510 (2005)

[6] R.Reyes, C.Legnani, M.Cremona, H.Brito, R.Britto, C. Achete, Physica Status Solidi (c) 1, 229 (2004)

[7] S. Van Slyke, C.Chen, C. Tang, Appl. Phys. Lett. 69, 2160 (1996)

[8] S.Carter, M. Angelopoulos, S.Karg, P.Brock, J.Scot, Appl. Phys. Lett. 70, 2067 (1997)

[9] Y.Kim, H.Park, J.Kim, Appl. Phys. Lett. 69, 599 (1996)

[10] Y.Gao, L.Wang, D.Zhang, L.Duan, G. Dong, Y.Qiu, Appl. Phys. Lett. 82, 155 (2003)

[11] H.Wang, L.Wang, Z. Wu, D.Zhang, J.Qiao, Y.Qiu, X.Wang, Appl. Phys. Lett. 88, 131113 (2006)

[12] B.J. Jung, J.-Ik Lee, H. Y. Chu, L.-M. Do, H.-K. Shim, Macromolecules 35, 2282 (2002)

[13] J. H. Park, Y. S. Lee, Y. H. Kwak, J. S. Choi, Journal of the Korean Physical Society 41, 1050 (2002)

[14] C.Legnani, R.Reyes, M.Cremona, I. Bagatin, H.Toma, Appl. Phys. Lett. 85, 10 (2004).

[15] X.Q.Wei, G.Yang, J.Cheng, Z.Y.Lu, M.G.Xie, Mat. Chem. Phys. 102, 214 (2007).

[16] Stojan Miloshev, Petia Petrova, Polymer Bulletin 56, 485 (2006)
[17] S. Forrest, D. Bradley, M. Thompson, Adv. Mater. 15 1043, (2003).

[18] K.Okamoto, H.Kanno, Y.Hamada, H.Takahashi, K.Shibata, Appl. Phys. Lett. 89, 013502 (2006).

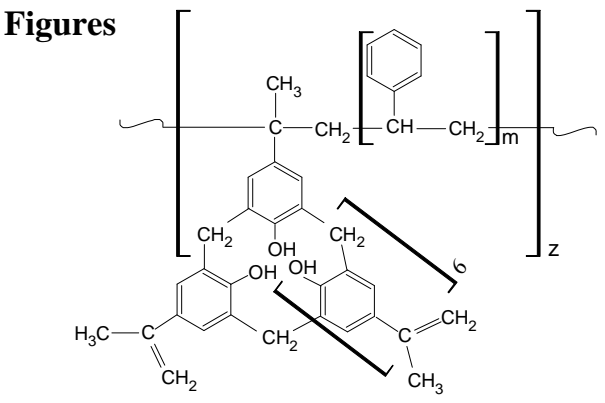

Figure 1. Chemical structure of the $p$ Isopropenylcalix[8]arenestyrene copolymer used in device fabrication as buffer layer.

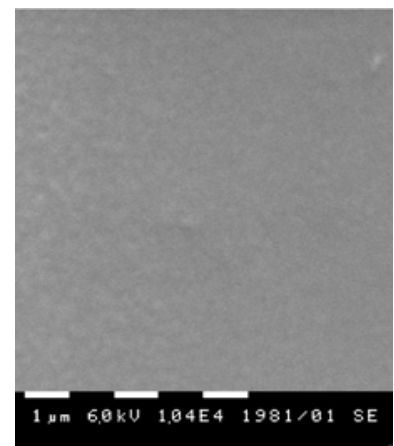

a) $\mathrm{PET} / \mathrm{ITO} / \mathrm{iPrCS}$

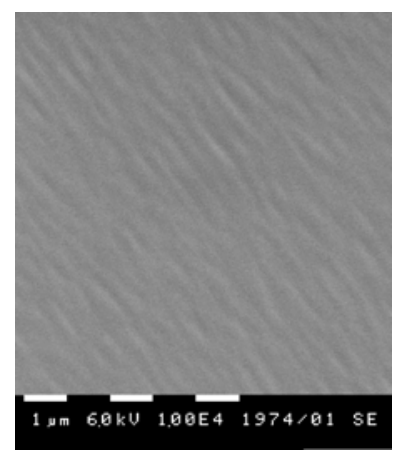

c) $\mathrm{PET} / \mathrm{ITO} / \mathrm{iPrCS} / \mathrm{TPD}$

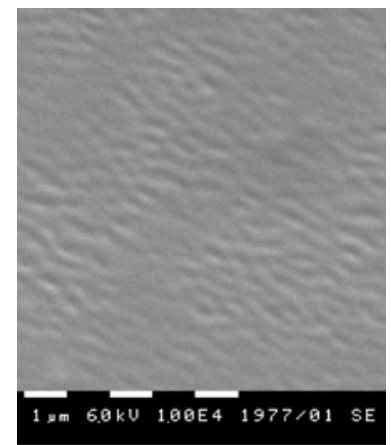

e) PET/ITO/iPrCS/TPD/Alq 3 $\mathrm{PET} / \mathrm{ITO} / \mathrm{TPD} / \mathrm{Alq}_{3}$

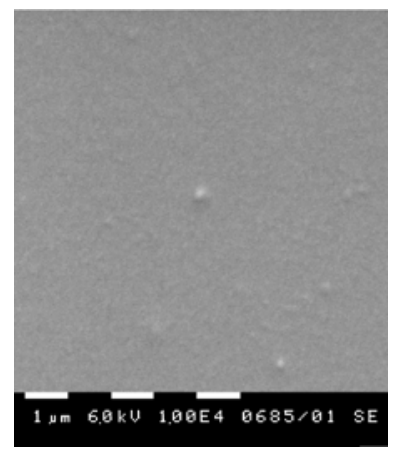

b) PET/ITO

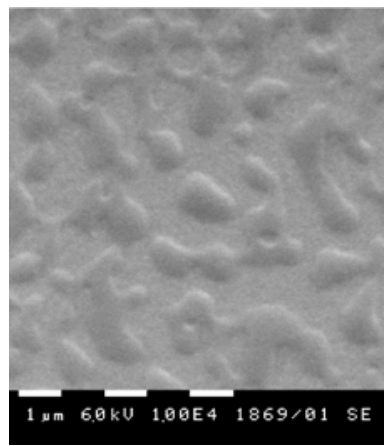

d) $\mathrm{PET} / \mathrm{ITO} / \mathrm{TPD}$

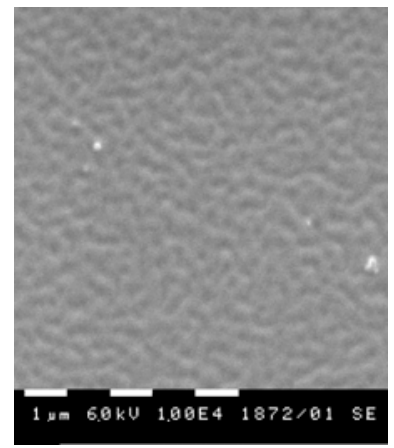

f)
Figure 2. SEM images 

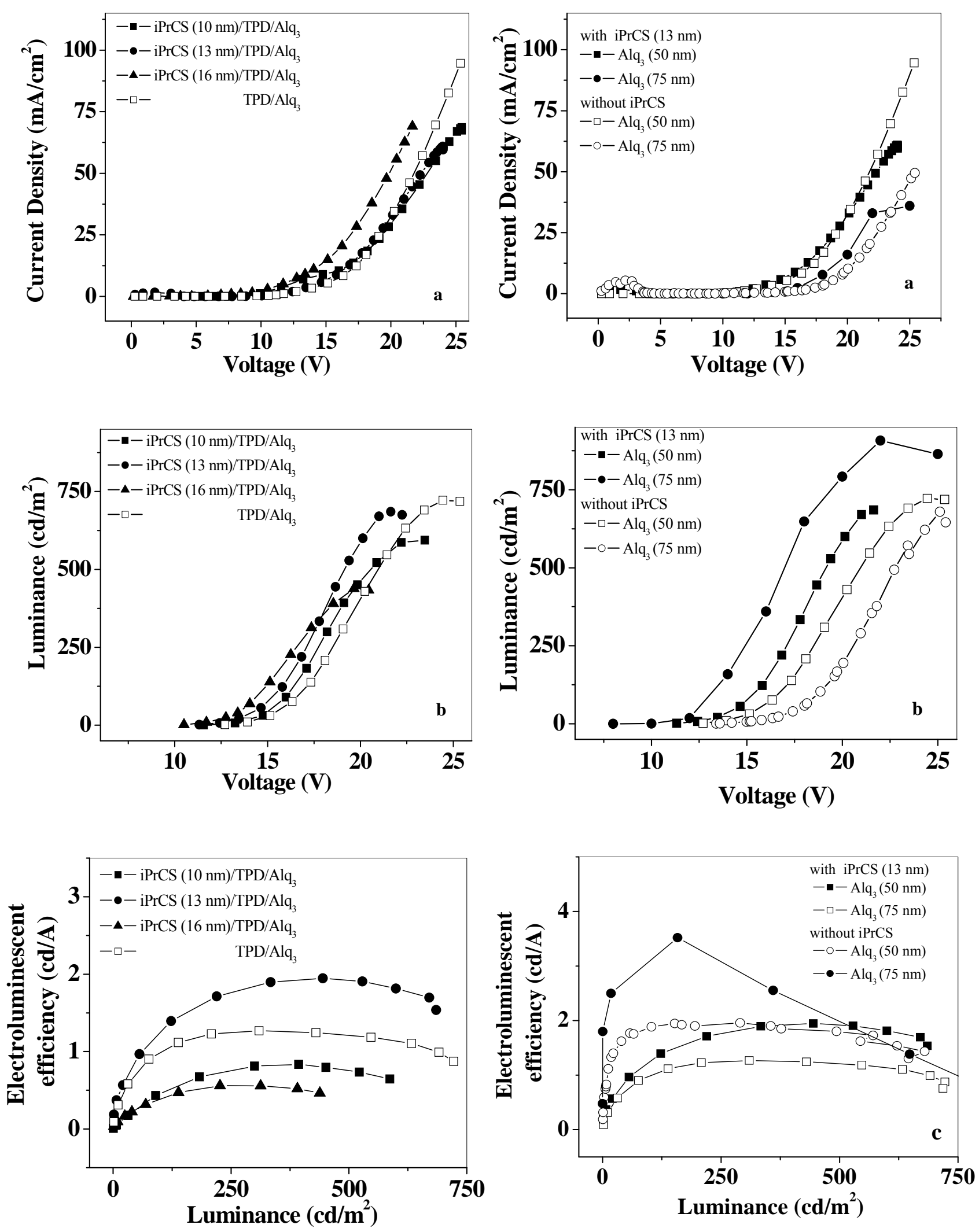

Figure 3. The current/voltage (3a), luminance/voltage (3b) and efficiency (3c) characteristics of ITO/iPrCS (10-16 nm)/TPD (30 $\mathrm{nm}) / \mathrm{Alq}_{3}(50 \mathrm{~nm}) / \mathrm{Al}$, and ITO/TPD $(30 \mathrm{~nm}) / \mathrm{Alq}_{3}$ (50 nm)/Al.

Figure 4. The current/voltage (4a), luminance/voltage (4b) and efficiency (4c) characteristics of the ITO/iPrCS (13 nm)/TPD (30 $\mathrm{nm}) / \mathrm{Alq}_{3}(50,75 \mathrm{~nm}) / \mathrm{Al}$, and ITO/TPD (30 $\mathrm{nm}) / \mathrm{Alq}_{3}(50,75 \mathrm{~nm}) / \mathrm{Al}$. 